\title{
PEMBANTUAN DAN PENYERTAAN (DEELMENING) DALAM KASUS PERKOSAAN ANAK
}

\author{
Ike Indra Agus Setyowati \\ Ikeindra4@gmail.com \\ Universitas Airlangga
}

\begin{abstract}
Rape is a sexual crime. Rape of children will destroy the future of children as the next generation. Nowadays the rape of children, as well as rape committed by children are getting increased. One of the contributing factors is due to the freedom of the child in accessing any information that can not be monitored continuously by parents. It encourages the children to commit acts that are not in accordance with their age and can not hold their lust. If the action is committed by an individual, it would be easy to identify the perpetrator. The problem occurs when it is committed by group. The case is included in the assistance and involvement in its responsibility. This paper discusses the implementation of the concept of assistance and involvement in cases of child rape that the perpetrator more than one person. In addition, it will analyzes Judge's consideration in the case of child rape on Court Decision Number 24 / Pid.Sus / A / 2012 / PN.Pso and Decision Case No 142/ Pid.Sus/2012/PN.Spg.
\end{abstract}

Keywords: Child rape; Responsibility in assistance and involvement.

\begin{abstract}
Abstrak
Perkosaan merupakan kejahatan seksual. Perkosaan terhadap anak akan merusak masa depan anak sebagai generasi penerus bangsa. Namun saat ini perkosaan terhadap anak ataupun perkosaan yang dilakukan oleh anak di bawah umur semakin ramai. Salah satu faktor yang menyebabkan adalah karena kebebasan anak dalam mengakses segala bentuk informasi yang tidak bisa diawasi terus menerus oleh orangtua. Hal tersebut yang mendorong anak untuk melakukan perbuatan yang tidak sesuai dengan umurnya dan tidak bisa membendung hawa nafsunya sehingga menyebabkan melakukan perkosaan terhadap temannya. Jika perbuatan tersebut dilakukan oleh perorangan, tentu akan mudah mengidentifikasi pelakunya. Namun, bila dilakukan secara bersama akan ditemukan kemungkinan bahwa kasus tersebut masuk dalan pembantuan dan penyertaan dalam pertanggungjawabannya. Tulisan ini membahas mengenai implementasi konsep penyertaan dan pembantuan dalam kasus perkosaan anak yang pelakunya lebih dari satu orang. Selain itu, juga akan di analisa pertimbangan Hakim dalam kasus perkosaan anak pada Putusan Pengadilan Nomor 24/Pid.Sus/A/2012/PN.Pso dan Putusan Perkara No 142/Pid.Sus/2012/PN.Spg.
\end{abstract}

Kata Kunci: Perkosaan Anak; Pertanggungjawaban Pembantuan dan Penyertaan.

\section{Pendahuluan}

Salah satu bentuk hak dasar yang harus diterima anak adalah jaminan untuk dapat tumbuh dan berkembang secara utuh baik fisik, mental maupun sosial serta berakhlak mulia. Jaminan perlindungan hak dasar tersebut sesuai dengan nilai Pancasila dan tujuan negara sebagaimana tercantum dalam Pembukaan Undangundang Dasar Negara Republik Indonesia tahun 1945 (UUD NRI tahun 1945). 
Disamping anak adalah amanah dan karunia Tuhan Yang Maha Esa, anak merupakan tunas, potensi, dan generasi muda penerus cita-cita perjuangan bangsa. Anak-anak inilah yang kemudian akan memiliki peran strategis yang mempunyai ciri dan sifat khusus untuk menjamin kelangsungan eksistensi bangsa dan negara di masa depan. Upaya-upaya perlindungan anak harus dimulai sedini mungkin, agar nantinya anak-anak dapat berpartisipasi secara optimal bagi pembangunan bangsa dan negara.

Selain itu dikarenakan menurut Pasal 1 (satu) butir 2 (dua) Undang-Undang No. 23 Tahun 2002 Tentang Perlindungan Anak (selanjutnya disebut UU No. 23/2002), perlindungan anak adalah memberi jaminan dan melindungi anak dan hakhaknya agar dapat hidup, tumbuh, berkembang, dan berpartisipasi, secara optimal sesuai dengan harkat dan martabat kemanusiaan, serta mendapat perlindungan dari kekerasan dan diskriminasi.

Bertambah majunnya perkembangan teknologi mempengaruhi tumbuh dan kembang anak-anak. Maraknya penggunaan gadget dan internet yang tidak bisa dikontrol lagi oleh orangtua bisa memicu sebuah sebab dari kasus perkosaan. Sangat mudahnya akses internet yang bisa dilakukan anak-anak di bawah umur tanpa diawasi oleh orangtua sehingga anak-anak dapat mengakses situs porno yang kemudian mereka menirunya dan terjadilah sebuah perkosaan yang tanpa mereka sadari dapat menghancurkan masa depan mereka juga korban dari pemerkosaan itu sendiri.

Berbagai kejahatan seksual baik dalam bentuk perzinahan, pemerkosaan, pencabulan maupun pelecehan seksual yang menimpa perempuan dewasa maupun anak-anak dapat berakibat pada penyebaran penyakit kelamin seperti AIDS. Tak jarang pula korban perkosaan yang sampai menyebabkan kehamilan. Perkosaan telah menjadi satu jenis kejahatan bidang seksual yang membutuhkan perhatian yang serius karena mengakibatkan persoalan yang serius dan beragam terutama kehidupan kaum perempuan, anak-anak dan masa depan suatu keluarga.

Tindak pidana perkosaan terhadap anak dibawah umur, termasuk pula ke dalam salah satu masalah hukum yang sangat penting untuk dikaji secara mendalam. 
Sebagaimana diketahui, tindak pidana perkosaan yang menimpa kaum wanita baik dewasa, remaja hingga anak merupakan perbuatan yang melanggar norma sosial yaitu kesopanan, agama dan kesusilaan.

Tindak kejahatan Pemerkosaan dengan korban anak yang masih di bawah umur dengan korban orang dewasa tentunya akan berbeda, baik dari penanganan korbanya maupun penegakan hukumnya. Korban pemerkosaan terhadap anak di bawah umur tentunya masih memiliki masa depan yang panjang yang seharusnya mampu dijaga dan dilindungi, karena merupakan generasi penerus kehidupan bangsa. Sanksi hukuman terhadap pelaku pemerkosaan terhadap anak yang masih di bawah umur telah diatur sendiri di dalam Undang-Undang Perlindungan Anak Nomor 35 Tahun 2014 Tentang Perubahan Undang-Undang Perlindungan Anak Nomor 23 Tahun 2002 Pasal 81 Butir 1,2,3.

Perlindungan anak merupakan upaya-upaya yang mendukung terlaksananya hak-hak dan kewajiban. Seorang anak yang memperoleh dan mempertahankan hak untuk tumbuh dan berkembang dalam hidup secara berimbang dan positif, berarti mendapat perlakuan secara adil dan terhindar dari ancaman yang merugikan. Usahausaha perlindungan anak dapat merupakan suatu tindakan hukum yang mempunyai akibat hukum, sehingga mengindarkan anak dari tindakan orangtua yang sewenangwenang. Implementasi konsep penyertaan dan pembantuan dalam kasus perkosaan anak yang pelakunya lebih dari satu orang

Wujud atau bentuk dari penyertaan deelneming yaitu turut melakukan medeplegen dan pembantuan (medeplichtigheid) yang dikandungan dalam Pasal 55 dan Pasal 56 Kitab Undang- Undang Hukum Pidana (KUHP). Tujuan dirumuskannya tindak pidana yang dalam undang-undang baik sebagai kejahatan ataupun pelanggaran ditujukan pada orang (subyek hukum pidana) dan hanya sebagian terdapat tindak pidana yang ditujukan pada suatu badan hukum yang terdapat diluar KUHP.

Subyek hukum yang disebutkan dan dimaksudkan dalam rumusan tindak pidana adalah hanya satu orang, bukan beberapa orang. Namun sering terjadi subyek suatu tindak pidana dilakukan lebih dari satu orang. Dalam hal ini dinamakan 
sebagai suatu penyertaan atau Deelneming. Penyertaan atau deelneming adalah pengertian yang meliputi semua bentuk turut serta/terlibatnya orang atau orangorang baik secara psikis maupun fisik dengan melakukan masing-masing perbuatan sehingga melahirkan suatu tindak pidana. ${ }^{1}$

Sedangkan dalam Kamus Besar Bahasa Indonesia “penyertaan” berasal dari kata serta yang memiliki arti ikut, mengikut, turut, dengan, bersama-sama dengan, beserta, mengiringi, menyertai, menemani, untuk membantu, iku-ikut, ikut campur, membarengi. ${ }^{2}$ Yang kemudian penyertaan memiliki arti turut sertanya seseorang atau lebih dalam suatu tindak pidana.

Penyertaan diatur di dalam Pasal 55 dan 56 Peraturan Perundang-undangan Nomor 1 tahun 1976 tentang Peraturan Hukum Indonesia (Kitab Undang-Undang Hukum Pidana). Pasal 55 dan 56 mengatur mengenai kategori dari perbuatan yang dilakukan termasuk dalam turut serta atau pembantuan apakah termasuk atau tidak.

Secara umum penyertaan dapat diartikan sebagai suatu perbuatan (tindak pidana) yang dilakukan lebih dari satu orang. Kata penyertaan (deelneming) berarti turut sertanya seseorang atau lebih pada waktu seseorang lain melakukan tindak pidana. Menurut VanHamel, memberikan definisi penyertaan sebagai ajaran pertanggungjawaban atau pembagian pertanggungjawaban dalam hal suatu tindak pidana yang menurut pengertian undang-undangan, dapat dilaksanakan oleh seorang pelaku dengan tindakan sendiri. ${ }^{3}$

Pengertian yang meliputi semua bentuk turut serta atau terlibatnya orang atau orang-orang baik secara psikis maupun fisik dengan melakukan masing-masing perbuatan sehingga melahirkan suatu tindak pidana. ${ }^{4}$

Dasar hukum penyertaan telah diatur dalam Pasal 55 dan Pasal 56 KUHP. Ketentuan pidana dalam Pasal 55 KUHP menurut rumusannya berbunyi:

\footnotetext{
${ }^{1}$ Adam Chazawi, Pelajaran Hukum Pidana Bagian I (Raja Grafindo Persada 2002).[73].

${ }^{2}$ Suharso dan Ana Retnoningsih, Kamus Besar Bahasa Indonesia Edisi Lux (Widya Karya 2014).[484].

${ }^{3}$ AK Moch Anwar, Beberapa Ketentuan Umum Dalam Buku I Kitab Undang-Undang Hukum Pidana (Alumni 2001).[3].

${ }^{4}$ Andi Hamzah, Asas-Asas Hukum Pidana Edisi Revisi (Rineka Cipta 2008).[51].
} 
(1) Dihukum sebagai pelaku-pelaku dari suatu tindak pidana, yaitu:

1. Mereka yang melakukan, menyuruh melakukan atau yang turut melakukan;

2. Mereka yang dengan pemberian-pemberian, janji-janji, dengan menyalahgunakan kekuasaan atau keterpandangan, dengan kekerasan, ancaman atau dengan menimbulkan kesalahpahaman atau dengan memberikan kesempatan, sarana-sarana atau keterangan-keterangan, dengan sengaja telah menggerakkan orang lain untuk melakukan tindak pidana yang bersangkutan.

(2) Mengenai mereka yang disebutkan terakhir ini, yang dapat dipertanggungjawabkan kepada mereka itu hanyalah tindakan-tindakan yang dengan sengaja telah mereka gerakkan untuk dilakukan oleh orang lain, berikut akibat-akibatnya.

Sedangkan ketentuan pidana dalam Pasal 56 KUHP menurut rumusannya berbunyi:(1). Mereka yang dengan sengaja telah memberikan bantuan dalam melakukan kejahatan tersebut. (2). Mereka yang dengan sengaja telah memberikan kesempatan, sarana-sarana atau keterangan-keterangan untuk melakukan kejahatan tersebut.

Menurut KUHP yang dimaksud dengan turut serta melakukan adalah setiap orang yang sengaja berbuat dalam melakukan suatu tindak pidana. Pada mulanya yang disebut dengan turut berbuat itu ialah bahwa masing-masing peserta telah melakukan perbuatan yang sama-sama memenuhi semua rumusan tindak pidana yang bersangkutan.

Lamintang mengemukakan bahwa, bentuk-bentuk deelneming atau keturut sertaan yang ada menurut Pasal 55 dan 56 KUHP adalah:

1. Doen plegen atau menyuruh melakukan atau yang di dalam doktrin juga sering disebut sebagai middellijk daderschap;

2. Medeplegen atau turut melakukan ataupun yang di dalam doktrin juga sering disebut sebagai mededaderschap;

3. Uitlokking atau menggerakkan orang lain, dan

4. Medeplichtigheid. ${ }^{5}$

Menurut Projodikoro bahwa dalam Pasal 55 dan Pasal 56 KUHP diadakan lima golongan peserta delik, yaitu:

1. Yang melakukan perbuatan (plegen, dader);

2. Yang menyuruh melakukan perbuatan (doen plegen, middelijke dader);

3. Yang turut melakukan perbuatan (medeplegen, mededader);

${ }^{5}$ PA. Lamintang, Dasar-Dasar Hukum Pidana Indonesia (Sinar Baru 1984).[101]. 
4. Yang membujuk supaya perbuatan dilakukan (uitlokken, uitlokker);

5. Yang membantu perbuatan (medeplichtig zijn, medeplichtige). ${ }^{6}$

Namun dalam Kitab Undang-Undang Hukum Pidana pada Pasal 55 jika dicermati menurut pengaturannya, menurut R. Soesilo dapat diketahui bahwa klasifikasi pelaku adalah :

1. Mereka yang melakukan (pleger)

Orang ini ialah seorang yang sendirian telah berbuat mewujudkan segala anasir atau elemen dari peristiwa pidana. Dalam peristiwa pidana yang dilakukan dalam jabatan misalnya orang itu harus pula memenuhi elemen status sebagai Pegawai Negeri

2. Mereka yang menyuruh melakukan (doen pleger)

Disini sedikitnya ada dua orang yang menyuruh (doen plegen) dan yang disuruh (pleger). Jadi bukan orang itu sendiri yang melakukan peristiwa pidana, akan tetapi ia menyuruh orang lain, meskipun demikian toh ia dipandang dan dihukum sebagai orang yang melakukan sendiri yang melakukan peristiwa pidana, akan tetapi ia menyuruh orang lain, disuruh (pleger) itu harus hanya merupakan suatu alat (instrument) saja, maksudnya ia tidak dapat dihukum karena tidak dapat dipertaggungjawabkan atas perbuatannya.

3. Orang yang turut melakukan (medepleger)

Turut melakukan dalam arti kata bersama-sama melakukan. Sedikit-dikitnya harus ada dua orang, ialah orang yang melakukan (pleger) dan orang yang turut melakukan (medepleger) peristiwa pidana itu. Disini diminta, bahwa kedua orang itu semuanya melakukan perbuatan pelaksanaan, jadi melakukan anasir atau elemen dari peristiwa pidana itu. Tidak boleh misalnya hanya melakukan perbuatan persiapan saja atau perbuatan yang sifatnya hanya menolong, sebab jika demikian, maka orang yang menolong itu tidak masuk medepleger akan tetapi dihukum sebagai membantu melakukan (medeplichtige) tersebut dalam pasal 56.

Dalam KUHP diatur mengenai perbuatan perkosaan terhadap perempuan

${ }^{6}$ Wirjono Prodjodikoro, Asas-Asas Hukum Pidana Di Indonesia (Refika Aditama 2011).[100]. 
pada Pasal 285, Pasal 286, Pasal 287. Yang termasuk tindak pidana biasa adalah yang diatur di dalam Pasal 285 dan Pasal 286 KUHP. Sedangkan Pasal 287 KUHP merupakan delik aduan, apabila yang bersangkutan (korban) berusia antara 12 sampai dengan 15 tahun. Dengan demikian terhadap Pasal 287 yang korbannya adalah perempuan berusia di bawah 12 tahun merupakan tindak pidana biasa. Jenis tindak pidana aduan dalam Pasal 287 menjadi gugur dan berubah menjadi tindak pidana biasa jika akibat persetubuhan tersebut menyebabkan anak yang berusia antara 12 sampai dengan 15 tahun tersebut mengalami luka, atau meninggal dunia. Tindak pidana aduan tersebut juga dapat berubah menjadi tindak pidana biasa apabila pelakunya adalah orang yang seharusnya memberikan perlindungan, mempunyai kewenangan atau berkewajiban memberikan bantuan secara professional kepada korban.

Pada Pasal 81 Ayat 1 UU No. 23/2002 Tentang Perlindungan Anak diatur mengenai persetubuhan dengan anak. Perbuatan yang diancam pidana dalam Pasal 81 Ayat 1 adalah persetubuhan dengan anak, yang diartikan sebagai suatu tindakan dengan memasukan alat kelamin pria (penis) ke dalam alat kelamin wanita (vagina). Persetubuhan yang dimaksud, dapat dikatakan sebagai tindakan pemerkosaan terhadap anak.

Teori Penyertaan Tindak Pidana Penyertaan (deelneming) terjadi apabila dalam suatu tindak pidana terlibat lebih dari satu orang. Sehingga harus dicari pertanggung jawaban masing-masing orang yang tersangkut dalam tindak pidana tersebut. Keterlibatan seseorang dalam suatu tindak pidana dapat dikategorikan sebagai:

1. Yang melakukan;

2. Yang menyuruh melakukan;

3. Yang turut melakukan;

4. Yang menggerakkan/menganjurkan untuk melakukan;

5. Yang membantu melakukan.

Dalam Pasal 81 Ayat 2 Undang-Undang Nomor 11 Tahun 2012 Tentang Sistem Peradilan Pidana Anak mengatur bahwa ancaman pidana penjara bagi anak yang melakukan tindak pidana adalah paling lama $1 / 2$ dari maksimum ancaman pidana penjara bagi orang dewasa. Kemudian dalam Pasal 55 Ayat 1 ke-1 KUHP 
disebutkan bahwa orang yang dihukum sebagai orang yang melakukan peristiwa pidana adalah orang yang melakukan (plegen), orang yang menyuruh melakukan (doen plegen) dan orang yang turut serta melakukan (medeplegen).

Orang yang melakukan adalah seseorang yang hanya sendirian saja telah melakukan atau mewujudkan seluruh unsur dari suatu tindak pidana, orang yang menyuruh melakukan adalah bukan orang itu sendiri yang melakukan tindak pidana akan tetapi menyuruh orang lain untuk melakukannya, akan tetapi yang disuruh itu haruslah hanya merupakan alat saja, ia tidak dapat dihukum karena tidak dapat dipertanggungjawabkan atas perbuatannya, sedangkan orang yang turut melakukan artinya dua orang atau lebih bersama-sama melakukan tindak pidana sedikitnya ada dua orang atau lebih yakni orang yang melakukan dan orang yang turut melakukan tindak pidana itu dan semuanya harus melakukan perbuatan pelaksanaan. Pertimbangan Hakim dalam kasus perkosaan anak Pada Putusan Pengadilan Nomor 24/Pid.Sus/A/2012/PN.Pso dan Putusan Perkara No 142/Pid.Sus/2012/PN.Spg.

Pada Putusan Pengadilan Nomor 24/Pid.Sus/A/2012/PN. Pso majelis hakim mempertimbangkan apakah perbuatan Para Terdakwa memenuhi unsur-unsur dalam dakwaan Jaksa Penuntut Umum dimana Para Terdakwa diajukan dipersidangan ini oleh Jaksa Penuntut Umum didakwa dengan dakwaan yang disusun secara alternatif. Berdasarkan prinsip "Lex Specialis Derogat Legi Generali”.

Maka Majelis akan mempertimbangkan dakwaan kesatu terlebih dahulu dimana Para Terdakwa didakwa melakukan perbuatan yang melanggar dan diancam pidana dalam pasal 81 Ayat 1 UU No. 23/2002 jo pasal 55 Ayat 1 ke-1 KUHP, dimana untuk dapat dipersalahkan melakukan tindak pidana sebagaimana diatur dalam pasal tersebut perbuatan Para Terdakwa harus memenuhi unsur-unsur : 1. Unsur Setiap Orang.2. Unsur sengaja melakukan kekerasan atau ancaman kekerasan memaksa anak melakukan persetubuhan dengannya atau dengan orang lain.

Majelis berpendapat bahwa keterangan saksi korban tidak bersesuaian dengan keterangan saksi Hernawan dan saksi Andi Nugroho yang menerangkan bahwa Para Terdakwa datang bersamaan di rumah saksi korban sesaat setelah saksi Hernawan dan saksi Andi Nugroho datang, saksi Hernawan mengajak saksi Andi 
Nugroho untuk datang ke rumah saksi korban untuk menanyakan tugas sekolah tanpa terlebih dahulu ditelpon olehTerdakwa III. (Keterangan saksi Hernawan dan Andi Nugroho tersebut ternyata bersesuaian dengan keterangan Para Terdakwa).

Atas keterangan saksi korban bahwa ketika didalam rumah saksi korban, Terdakwa I minta maaf kepada saksi korban karena telah melakukan persetubuhan dengan saksi korban. Keterangan saksi korban tersebut tidak bersesuaian dengan keterangan saksi Hernawan yang menerangkan bahwa memang benar Terdakwa I minta maaf kepada saksi korban tetapi bukan karena telah melakukan persetubuhan tetapi karena Terdakwa I telah mengambil memory card milik saksi korban. (keterangan saksi Hernawan tersebut ternyata bersesuaian dengan keterangan Terdakwa I Naldin).

Berdasarkan pertimbangan Hakim ditambah fakta bahwa keteranganketerangan saksi korban banyak yang tidak bersesuaian dengan keterangan saksi Hernawan dan saksi Andi Nugroho yang juga datang pada malam itu, maka hal tersebut menjadikan Majelis Hakim tidak memperoleh keyakinan akan keteranganketerangan saksi korban bahwa Para Terdakwa telah melakukan persetubuhan terhadap saksi korban.

Majelis Hakim mempertimbangkan dakwaan kedua, dimana Para Terdakwa didakwa melakukan perbuatan yang melanggar dan diancam pidana dalam pasal 286 KUHP jo pasal 55 Ayat 1 ke-1 KUHP, dimana untuk dapat dipersalahkan melakukan tindak pidana sebagaimana diatur dalam pasal tersebut perbuatan Para Terdakwa harus memenuhi unsur-unsur : 1. Unsur Barangsiapa. 2. Unsur Bersetubuh dengan seorang wanita diluar perkawinan. 3. Unsur padahal diketahui bahwa wanita itu dalam keadaan pingsan atau tidak berdaya.

Karena perbuatan Para Terdakwa tidak memenuhi seluruh unsur dalam dakwaan kedua maka Para Terdakwa tidak terbukti secara sah dan menyakinkan melakukan perbuatan dalam dakwaan kedua penuntut umum dan oleh karenanya Para Terdakwa harus dibebaskan dari dakwaan kedua Penuntut umum.

Karena Para Terdakwa telah tidak terbukti secara sah dan menyakinkan melakukan perbuatan dalam dakwaan kedua Penuntut umum maka selanjutnya 
Majelis akan mempertimbangkan dakwaan ketiga, dimana Para Terdakwa didakwa melakukan perbuatan yang melanggar dan diancam pidana dalam pasal $290 \mathrm{ke}-1$ KUHP jo pasal 55 Ayat 1 ke-1 KUHP, dimana untuk dapat dipersalahkan melakukan tindak pidana sebagaimana diatur dalam pasal tersebut perbuatan Para Terdakwa harus memenuhi unsur-unsur : 1. Unsur Barangsiapa. 2. Unsur melakukan perbuatan cabul dengan seorang wanita. 3. Unsur padahal diketahui bahwa wanita itu pingsan atau tidak berdaya.

Sesuai pertimbangan dari keterangan antara keterangan Terdakwa ditambah fakta bahwa keterangan-keterangan saksi korban banyak yang tidak bersesuaian dengan keterangan saksi Hernawan dan saksi Andi Nugroho yang juga datang pada malam itu, maka hal tersebut menjadikan Majelis Hakim tidak memperoleh keyakinan bahwa Para Terdakwa telah melakukan perbuatan cabul terhadap saksi korban. Mengenai keterangan Para Terdakwa dalam BAP Penyidik telah dipertimbangkan dalam dakwaan kesatu dan selanjutnya diambil alih dan menjadi pertimbangan dalam dakwaan ketiga.

Maka keterangan Para Terdakwa yang dipertimbangkan adalah keterangan dimuka persidangan dimana Para Terdakwa telah menerangkan bahwa Para Terdakwa berada di rumah saksi korban hanya sampai jam 24.00 wita dan kemudian Para Terdakwa pulang ke rumah masing-masing. Menurut Hakim berdasarkan pertimbangan-pertimbangan tersebut maka Para Terdakwa telah tidak terbukti melakukan perbuatan yang melanggar kesusilaan(kesopanan) atau perbuatan yang keji dalam lingkungan nafsu birahi kelamin sehingga Para Terdakwa tidak terbukti telah melakukan perbuatan cabul terhadap saksi korban. Berdasarkan pertimbangan Hakim, maka unsur kedua dalam dakwaan ketiga telah tidak terpenuhi.

Karena unsur ke dua pada dakwaan ketiga telah tidak terpenuhi maka Majelis Hakim merasa tidak perlu mempertimbangkan unsur selebihnya dari dakwaan ketiga. Menurut Hakim perbuatan Para Terdakwa tidak memenuhi seluruh unsur dalam dakwaan ketiga maka Para Terdakwa tidak terbukti secara sah dan menyakinkan melakukan perbuatan dalam dakwaan ketiga penuntut umum dan oleh karenanya Para Terdakwa harus dibebaskan dari dakwaan ketiga Penuntut umum. 
Pasal 183 KUHAP menyatakan bahwa hakim tidak boleh menjatuhkan pidana kepada seorang kecuali apabila sekurang-kurangnya dua alat bukti yang sah ia memperoleh keyakinan bahwa suatu tindak pidana benar-benar telah terjadi dan bahwa terdakwalah yang bersalah melakukannya. Dapat diartikan bahwa untuk membuktikan seorang terdakwa bersalah atau tidak, maka hakim harus mempunyai dua alat bukti yang sah menurut undang-undang. Selanjutnya, dua alat bukti tersebut harus didukung dengan keyakinan hakim untuk menentukan terdakwa bersalah atau tidak.

Dalam hukum pidana dikenal ada beberapa jenis alat bukti. Dalam Pasal 184 Ayat 1 Kitab Undang-Undang Hukum Acara Pidana (KUHAP) menyatakan:

"Alat bukti yang sah ialah :
a. Keterangan saksi;
b. Keterangan ahli;
c. Surat;
d. Petunjuk;
e. Keterangan terdakwa."

Bukti visum et repertum (visum) dikategorikan sebagai alat bukti surat. Hal ini didasarkan pada ketentuan Pasal 187 KUHAP yang menyatakan:

"Surat sebagaimana tersebut pada Pasal 184 Ayat 1 huruf c, dibuat atas sumpah jabatan atau dikuatkan dengan sumpah, adalah:

a. Berita acara dan surat lain dalam bentuk resmi yang dibuat oleh pejabat umum yang berwenang atau yang dibuat di hadapannya, yang memuat keterangan tentang kejadian atau keadaan yang didengar, dilihat atau yang dialaminya sendiri, disertai dengan alasan yang jelas dan tegas tentang keterangannya itu;

b. Surat yang dibuat menurut ketentuan peraturan perundang-undangan atau surat yang dibuat oleh pejabat mengenai hal yang termasuk dalam tata laksana yang menjadi tanggungjawabnya dan yang diperuntukkan bagi pembuktian sesuatu keadaan;

c. Surat keterangan dari seorang ahli yang memuat pendapat berdasarkan keahliannya mengenai sesuatu hal atau suatu keadaan yagn diminta secara resmi dari padanya;

d. Surat lain yang hanya dapat berlaku jika ada hubungannya dengan isi dari alat pembuktian yang lain."

Dari sini dapat ditarik sebuah kesimpulan bahwa visum merupakan surat yang dibuat oleh pejabat dan dibuat atas sumpah jabatan berdasarkan ketentuan peraturan perundang-undangan. Oleh karena itu, visum masuk dalam kategori alat bukti surat. Dengan demikian visum memiliki nilai pembuktian di persidangan. 
Namun visum bukanlah satu-satunya alat bukti yang dapat membuktikan adanya tindak pidana dalam perkosaan. Kasus tindak pidana perkosaan sulit dibuktikan karena yang terlibat hanya antara pelaku dan korban. Namun dapat digali berdasarkan keterangan dari korban dan saksi.

Pada putusan Pengadilan Nomor 24/Pid.Sus/A/2012/PN.Pso Hakim memutuskan bahwa para tersangka tidak bersalah dan bebas dari dakwaan Penuntut Umum. Hal ini didasarkan karena Hakim kurang yakin dengan bukti yang ada berdasarkan keterangan korban yang dicocokkan dengan keterangan tersangka.

Dalam hal ini alat bukti yang sah menurut KUHAP ialah keterangan saksi, keterangan ahli, surat, petunjuk, keterangan terdakwa. Dengan adanya aturan ini urutan yangutama adalah berdasarkan keterangan saksi, yang dalam hal ini saksi adalah saksi korban. Mengenai petunjuk dan keterangan terdakwa posisinya berada di bawah keterangan saksi. Dalam pertimbangan Ketua Majelis dan Hakim Anggota I mengenai bukti surat berupa visum tidak dipertimbangkan. Sedangkan dalam visum ditemukan bahwa ada luka terhadap vagina korban. Ketua Majelis dan Hakim Anggota I cenderung memertimbangkan dari keterangan terdakwa.

Mengenai alat bukti, penyidik dapat menyita sprei yang menurut keterangan terdakwa pada saat penyidikan menyatakan bahwa terdakwa II dan terdakwa III mengeluarkan spermanya di sprei tersebut. Begitu juga pada Putusan Perkara No 142/ Pid.Sus/2012/PN.Spg Terdakwa didakwa dengan dakwaan tunggal, yaitu melanggar 56 Ayat 1 dan 2 KUHP jo. Pasal 81 Ayat 1 UU No. 23/2002, yang mengandung unsurunsur sebagai berikut : Setiap orang; Dengan sengaja membantu, memberi kesempatan, sarana atau keterangan untuk melakukan kekerasan atau ancaman kekerasan, memaksa anak melakukan persetubuhan dengannya atau dengan orang lain.

Bahwa pada saat kejadian tersebut, saksi korban adalah dalam kategori "anak", karena masih berusia 16 tahun (belum mencapai 18 tahun). Majelis memandang, Terdakwa sebagai seorang yang telah dewasa dan sehat secara jasmani maupun rohani, jugaseharusnya mengetahui bahwa perbuatan yang dilakukannya tersebut merupakan perbuatan yang melanggar kesopanan dan kesusilaan. Hal tersebut dilakukan oleh Terdakwa dengan penuh kesadaran dan Terdakwa dapat mengetahui 
akibat dari perbuatannya tersebut, yaitu saksi korban merasa malu dan tidak terima dengan perlakuan Terdakwa dan saksi demah.

Berdasarkan uraian pertimbangan Hakim, maka Majelis Hakim berpendapat terhadap unsur ke-1 ini telah terpenuhi menurut hukum dan telah terbukti “dengan sengaja membantu saksi demah menyetubuhi anak secara paksa dengan menggunakan kekerasan”, dengan demikian unsur kedua ini telah terpenuhi pula bahwa dengan sengaja memberi bantuan, kesempatan, sarana atau keterangan untuk melakukan kekerasan atau ancaman kekerasan, memaksa anak melakukan persetubuhan dengannya atau dengan orang lain.

Majelis Hakim berpendapat bahwa Terdakwa telah terbukti dengan sengaja membantu saksi demah menyetubuhi anak secara paksa dengan menggunakan kekerasan. Dengan demikian unsur kedua ini telah terpenuhi pula menurut hukum.

Oleh karena semua unsur-unsur yang terdapat dalam Pasal 56 Ayat 1 dan 2 KUHP jo. Pasal 81 Ayat 1 UU No. 23/2002 telah terpenuhi, maka Terdakwa haruslah dinyatakan terbukti secara sah dan meyakinkan melakukan tindak pidana sebagaimana dakwaan primair Penuntut Umum.

Hakim juga mempertimbangkan bahwa selama di persidangan tidak ditemukan alasan pembenar maupun alasan pemaaf dalam diri atau perbuatan Terdakwa yang dapat menghapus kesalahannya, sehingga Terdakwa haruslah dinyatakan bersalah dan dijatuhi pidana yang setimpal dan sepadan dengan perbuatannya.

Karena ancaman pidana dalam pasal dakwaan yang terbukti bersifat komulatif, meliputi pidana penjara dengan pidana denda, maka Majelis akan menjatuhkan kedua jenis pidana tersebut kepada terdakwa dengan ketentuan terhadap pidana denda apabila tidak dibayar akan diganti dengan pidana kurungan yang lamanya akan ditentukan dalam amar putusan.

Dalam menentukan jenis dan pidana yang akan dijatuhkan kepada Terdakwa, terlebih dahulu Majelis Hakim mempertimbangkan hal-hal apa saja yang memberatkan maupun yang meringankan bagi diri Terdakwa, yaitu sebagai berikut: Hal-Hal Yang Memberatkan:

1. Perbuatan Terdakwa menimbulkan rasa sakit dan malu bagi saksi korban pada 
khusunya dan keluarga saksi korban pada umumnya;

2. Terdakwa tidak berterus terang dalam memberikan keterangan di persidangan. Hal-Hal Yang Meringankan:

1. Terdakwa belum pernah dihukum;

2. Terdakwa bersikap sopan selama persidangan;

3. Terdakwa mempunyai anak yang masih kecil, yang mana anak tersebut masih membutuhkan perawatan dan kasih sayang dari seorang ibu.

Terdakwa Khusnul Khotimah alias uus telah terbukti secara sah dan meyakinkan bersalah melakukan tindak pidana "Membantu Melakukan Perkosaan terhadap Anak" berdasarkan fakta-fakta yang ada dalam persidangan. Pertimbangan hakim pada Putusan Nomor : 142/Pid.Sus/2012/PN.Spg hanya terfokuskan kepada konsep tindak pidana perkosaan yang terjadi saja. Namun dari kronologi kejadian perkara tersebut ada unsur dari tindak pidana lain yang bisa digali berdasarkan kronologi kejadian, yaitu unsur penculikan sesuai Pasal 328 KUHP. Terbukti dengan adanya keterangan dari saksi korban bahwa: Saksi korban keluar rumah langsung pergi ke timur rumahnya ke arah rumah saksi uus, sesampainya di timur rumahnya tiba-tiba saksi korban melihat seorang laki-laki yang tidak dikenal (saksi demah) sudah menunggu dan menarik tangan saksi korban secara paksa hingga saksi korban terjatuh duduk, kemudian saksi korban dipaksa lagi untuk naik ke sepeda motornya dan saksi korban bertanya kepada saksi demah "kamu siapa" lalu saksi demah menjawab kalau saksi demah disuruh uus menjemput saksi korban, karena saksi korban takut, selanjutnya saksi korban ikut saksi demah menuju rumah Terdakwa.

Bahwa sesampainya di rumah Terdakwa, saksi dibawa ke dalam rumah Terdakwa dan menuju sebuah kamar, sedangkan saksi demah masih berada di luar rumah Terdakwa. Setelah itu saksi dibawa masuk ke kamar Terdakwa dan Terdakwa bilang kepada saksi untuk menunggu disini, lalu saksi menjawab: "Iya Mbak", kemudian Terdakwa meninggalkan saksi sendirian di dalam kamar dan menguncinya dari luar,kemudian saksi mendengar percakapan antara Terdakwa dengan saksi demah, kemudian lampu kamar tersebut dimatikan dari luar, sehingga saksi ketakutan. 
Dimulai dari hari Senin tanggal 23 April 2012 sampai dengan hari Minggu tanggal 29 April 2012 dinihari sekira pukul 01.30 wib saksi menelpon Terdakwa dan berpura-pura mengaku sebagai demah dan menanyakan keberadaan korban kepada Terdakwa dan kemudian Terdakwa memberitahu saksi: "Barusan suiri dan Suedi (Saksi) datang kerumah saya untuk mencari korban dan ingin memaksa membuka kamar yang ditempati korban, namun saya mengatakan kunci kamar tersebut dibawa orang tua saya sehingga suiri dan suedi tidak berhasil membuka pintu kamar tersebut dan tidak berhasil menemukan keberadaan korban", dan kemudian telepon tersebut saksi matikan dan tepatnya pukul 02.00 saksi mengajak suiri berangkat kembali rumah Terdakwa dan melakukan apa yang dikatakan Ibu Mertua dan akhirnya Terdakwa tidak bisa berbohong bahwa kuncinya ada padanya dan kemudian pintu kamar dibuka sendiri oleh Terdakwa dan ditemukan saksi korban ada didalamnya.

Dalam rentang waktu antara tanggal 23 April 2012 sampai dengan tanggal 29 April 2012 Saksi Korban disekap di salah satu kamar dalam rumah Terdakwa. Selain itu, dalam penggalian fakta di awal sebelum persidangan Jaksa juga seharusnya mempertimbangkan dakwaannya dengan memperhatikan dari kronologi kejadian. Terjadinya penyekapan yang dilakukan oleh Tedakwa uus termasuk ke dalam tindak pidana yang berdiri sendiri namun masih dalam satu rangkaian kejadian dalam proses perkosaan anak di bawah umur yang dilakukan oleh Saksi demah. Dalam dakwaan mengenai tindak pidana penyekapan tidak digali oleh Jaksa di dalam Dakwaan. Jadi, dari perbuatan pembantuan oleh tersangka tersebut juga terdapat tindak pidana lainnya yaitu penyekapan terhadap saksi korban.

Mengenai putusan yang diberikan kepada Terdakwa khusnul khotimah alias uus yang telah terbukti secara sah dan meyakinkan bersalah melakukan tindak pidana "Membantu Melakukan Perkosaan terhadap Anak" dengan menjatuhkan pidana kepada Terdakwa dengan pidana penjara selama 7 (tujuh) tahun dan denda sebesar Rp. 60.000.000,- (enam puluh juta rupiah) dan apabila denda tersebut tidak dibayar, maka diganti dengan pidana kurungan selama 2 (dua) bulan sudah sesuai. 
Dari keterangan para saksi juga menjadi bahan pertimbangan dari Hakim dalam penjatuhan pidana mengenai Terdakwa yang melakukan Tindak Pidana Pembantuan dalam perkosaan anak. Terdakwa secara sacara dan berakal sehat dalam melakukan perbutan pebantuan tersebut. Bahkan dengan sengaja menutupi karena sewaktu Saksi Suiri dan Suedi dating ke rumahnya menyembunyikan Saksi Korban di kamar yang dipakai untuk menyekapnya.

Dari kedua putusan tersebut memiliki perbedaan karena pada putusan pertama seluruhnya baik korban atau pelaku merupakan anak. Dan hakim tentu mengambil keputusan berdasarkan kebaikan kedua belah pihak dikarenakan masih anak-anak. Namun penggalian fakta dalam persidangan kurang karena hakim cenderung mendengarkan kesaksian dari pihak terdakwa saja. Ketidaksamaan antara keterangan dari saksi dan terdakwa seharusnya menjadikan alasan agar lebih digali lagi terhadap fakta-fakta yang sebenarnya dan pencarian alat bukti lain yang ada di tempat kejadian perkara. kondisi non yuridis dari korban juga harus menjadi pertimbangan karena terdakwa dibebaskan dari hukuman. Sedangkan pada putusan kedua penggalian fakta yang ada juga masih kurang, karena ada unsur tindak pidana lain yang dapat ditemukan.

\section{Kesimpulan}

Wujud atau bentuk dari penyertaan (deelneming) yaitu turut melakukan (medeplegen) dan pembantuan (medeplichtigheid) yang dikandungan dalam Pasal 55 dan Pasal 56 Kitab Undang- Undang Hukum Pidana KUHP. Menurut KUHP yang dimaksud dengan turut serta melakukan adalah setiap orang yang sengaja berbuat dalam melakukan suatu tindak pidana. Pada mulanya yang disebut dengan turut berbuat itu ialah bahwa masing-masing peserta telah melakukan perbuatan yang sama-sama memenuhi semua rumusan tindak pidana yang bersangkutan.Pada dasarnya perkosaan terhadap anak yang dilakukan oleh lebih dari satu orang adalah tindakan pemaksaan oleh laki-laki kepada wanita yang mash anak-anak ataupun sudah dewasa untuk melakukan hubungan seksual selayaknya suami dan isteri. Kemudian mengenai penyertaan dan pembntuannya, penyertaan dapat dilakukan 
oleh pelaku yang lebih dari satu orang dengan cara pemberian sarana untuk terciptanya perkosaan tesebut.Pembantuan atau "membantu" melakukan tindak pidana dalam Pasal 56 KUHP, maka harus dibuktikan adanya unsur "sengaja" pada tindakan untuk membantu melakukan tindak pidana. Membantu melakukan adalah memberikan sarana untuk pelaku utama melakukan tindak pidana perkosaan dengan memberikan sarana dan mengetahuibahwa akan dilakukan perkosaan, maka unsur sengaja terkandung di dalamnya.

Pada putusan Pengadilan Nomor 24/Pid.Sus/A/2012/PN.Pso Hakim memutuskan bahwa para tersangka tidak bersalah dan bebas dari dakwaan Penuntut Umum. Hal ini didasarkan karena Hakim kurang yakin dengan bukti yang ada berdasarkan keterangan korban yang dicocokkan dengan keterangan tersangka. Dalam putusan, pertimbangan Ketua Majelis dan Hakim Anggota I mengnai bukti surat berupa visum tidak dipertimbangkan. Sedangkan dalam visum ditemukan bahwa ada luka terhadap vagina korban. Ketua Majelis dan Hakim Anggota I cenderung mempertimbangkan dari keterangan terdakwa. Sedangkan pada Putusan Nomor 142/ Pid.Sus/2012/PN.Spg dalam penggalian fakta di awal sebelum persidangan Jaksa juga seharusnya mempertimbangkan dakwaannya dengan memperhatikan dari kronologi kejadian. Terjadinya penyekapan yang dilakukan oleh Tedakwa uus termasuk ke dalam tindak pidana yang berdiri sendiri namun masih dalam satu rangkaian kejadian dalam proses perkosaan anak di bawah umur yang dilakukan oleh Saksi demah. Dalam dakwaan mengenai tindak pidana penyekapan tidak digali oleh Jaksa di dalam Dakwaan. Jadi, dari perbuatan pembantuan oleh tersangka tersebut juga terdapat tindak pidana lainnya yaitu penyekapan terhadap saksi korban.

\section{Daftar Bacaan}

\section{Buku}

Adam Chazawi, Pelajaran Hukum Pidana bagian I (Raja Grafindo Persada 2002).

Suharso dan Ana Retnoningsih, Kamus Besar Bahasa Indonesia Edisi Lux (Widya Karya 2014).

AK Moch Anwar, Beberapa Ketentuan Umum dalam Buku I Kitab Undang-undang 
Hukum Pidana (Alumni 2001).

Andi Hamzah, Asas-Asas Hukum Pidana Edisi Revisi (Rineka cipta 2008).

P.A.F Lamintang, Dasar-Dasar Hukum Pidana Indonesia (Sinar Baru 1984).

Wirjono Prodjodikoro, Asas-asas Hukum Pidana di Indonesia (Refika Aditama 2011).

\section{Perundang-undangan}

Pembukaan Undang-undang Dasar Negara Republik Indonesia tahun 1945 (UUD NRI tahun 1945).

Undang-Undang Nomor 1 Tahun 1976 tentang Peraturan Hukum Pidana (disingkat Kitab Undang-undang Hukum Pidana atau KUHP).

Undang-Undang Nomor 8 Tahun 1981 tentang Hukum Acara Pidana (disingkat Kitab Undang-Undang Hukum Acara Pidana atau KUHAP).

Undang-undang Nomor 1 Tahun 2002 tentang Perlindungan Anak (Lembaran Negara Republik Indonesia Tahun 2002 Nomor 109).

Undang-Undang Nomor 11 Tahun 2012 tentang Sistem Peradilan Pidana Anak (Lembaran Negara Republik Indonesia Tahun 2012 Nomor 153).

Undang-Undang Nomor 35 Tahun 2014 tentang Perubahan Undang-Undang Nomor 23 Tahun 2002 tentang Perlindungan Anak (Lembaran Negara Republik Indonesia Tahun 2014 Nomor 297).

HOW TO CITE: Ike Indra, 'Pembantuan Dan Penyertaan (Deelmening) Dalam Kasus Perkosaan Anak' (2018) Vol. 1 No. 2 Media Iuris. 